\title{
Revision of Rhamphomyia species (Diptera: Empididae) described by A.E. Holmgren from Novaya Zemlya Islands
}

\author{
Ревизия видов Rbamphomyia (Diptera: Empididae), \\ описанных А.Э. Хомьмгреном с островов Новая Земля
}

\author{
I.V. Shamshev', B.J. Sinclair ${ }^{2}$ \\ И.В. Шамшев ${ }^{1}$, Б.Алк. Синклер ${ }^{2}$
}

\footnotetext{
${ }^{1}$ Zoological Institute, Russian Academy of Sciences, Universitetskaya nab. 1, St. Petersburg 199034, Russia. E-mail: shamshev@mail.ru Зоологический институт РАН, Университетская наб. 1, С.-Петербург 199034, Россия.

${ }^{2}$ Canadian National Collection of Insects \& Canadian Food Inspection Agency, OPL-Entomology, K.W. Neatby Bldg., C.E.F., 960 Carling Ave., Ottawa, ON, K1A 0C6, Canada E-mail: bradley.sinclair@canada.ca
}

KEYWORDS. Diptera, Empididae, Rhamphomyia, type specimens, Novaya Zemlya, Palaearctic. КЛЮЧЕВЫЕ СЛОВА. Diptera, Empididae, Rhamphomyia, типовые экземпляры, Новая Земля, Палеарктика.

ABSTRACT. The type material of four species of dance flies of the genus Rhamphomyia Meigen, 1822 collected from Novaya Zemlya Archipelago and Vaygach Island by the Swedish Expedition of A.E. Nordenskiöld to Enisey River (1875) and described by Swedish entomologist A.E. Holmgren are examined: Rhamphomyia (Dasyrhamphomyia) brusewitzii Holmgren, 1880; R. (D.) hovgaardii Holmgren, 1880; R. (Pararhamphomyia) kjellmanii Holmgren, $1880 ;$ R. (P.) nordqvistii Holmgren, 1880. Rhamphomyia (Dasyrhamphomyia) brusewitzii Holmgren, 1880, stat.n., is raised from synonymy. Lectotypes are designated and re-descriptions are provided for all four species. The male of $R$. (P.) kjellmanii is described for the first time.

РЕЗЮМЕ. Изучен типовой материал четырёх видов мух толкунчиков рода Rhamphomyia Meigen, 1822, собранных на архипелаге Новая Земля и острове Вайгач Шведской экспедицией А.Э. Норденшельда к реке Енисей (1875), и описанных Шведским энтомологом А.Э. Хольмгреном: Rhamphomyia (Dasyrhamphomyia) brusewitzii Holmgren, 1880; R. (D.) hovgaardii Holmgren, 1880; R. (Pararhamphomyia) kjellmanii Holmgren, 1880; $R$. (P.) nordqvistii Holmgren, 1880. Rhamphomyia (Dasyrhamphomyia) brusewitzii Holmgren, 1880, stat.n., восстановлен из синонимии. Для всех четырёх видов обозначены лектотипы и даныпереописания. Впервые описан самец $R$. (P.) kjellmanii.

\section{Introduction}

The dance-flies, or Empididae, are a large family of Diptera distributed worldwide and inhabiting very different biotopes. Among the latter, empidids belong to a quite small community of flies occurring on arctic tundra, penetrating the islands of the Arctic Ocean.

Swedish entomologist August Emil Holmgren (18291888) worked primarily on Hymenoptera, but described four species of the empidid genus Rhamphomyia Meigen, 1822 taken from the Novaya Zemlya Archipelago and Vaygach Island of Arctic Russia: R. brusewitzii Holmgren, 1880; R. hovgaardii Holmgren, 1880; R. kjellmanii Holmgren, 1880; $R$. nordqvistii Holmgren, 1880. These flies were collected by the expedition of A.E. Nordenskiöld, a famous Swedish explorer of the Arctic, during his first voyage to Enisey River of Siberia [1875]. Holmgren published firstly descriptions of these species of Rhamphomyia in a separate booklet [Holmgren, 1880] and later he repeated them in a joint paper with C. Aurivillius [Holmgren, Aurivillius, 1883]. It is evident that Holmgren [1880] dedicated his first paper to the triumphal return to Stockholm (24 April 1880) of A.E. Nordenskiöld after his voyage on the Vega which navigated for the first time the entire length of the Northeast Passage. The cover of the paper bears an inscription to A.E. Nordenskiöld. In addition, Holmgren provided a special preface and named his new species in honour of some members of the Expedition (E.O. Brusewitz, Lieutenant in the Royal Swedish Navy, second in command of the vessel; A. Hovgaard, Lieutenant in the Royal Danish Navy, superintendent of the magnetical and meteorological work of the expedition; F.R. Kjellman, Docent in Botany at the University of Uppsala, superintendent of the botanical work of the expedition; O. Nordquist (Finnish-born), Lieutenant of the Imperial Russian Regiment of Guards, interpreter, and assistant zoologist participated in the Expedition from the Russian Geographic Society [Leslie, 1879]).

How to cite this article: Shamshev I.V., Sinclair B.J. 2018. Revision of Rhamphomyia species (Diptera: Empididae) described by A.E. Holmgren from Novaya Zemlya Islands // Russian Entomol. J. Vol.27. No.3. P.307314. doi: 10.15298/rusentj.27.3.13 
The type localities of these species are uncertain. Holmgren [1880] did not indicate them in his original descriptions, but given the title of his paper it is likely "Novaya Zemlya", which has been accepted by later authors. In his subsequent paper, Holmgren [Holmgren, Aurivillius, 1883] indicated more precise localities (except $R$. nordqvistii) and even notes Vaygach Island for $R$. hovgaardii. Our paper provides detailed information on the species of Rhamphomyia described by A.E. Holmgren including label data, current taxonomic status, re-descriptions and images. The lectotypes are designated for all species.

\section{Material and methods}

Four species of Rhamphomyia described by A.E. Holmgren are housed in the Naturhistoriska Riksmuseet, Stockholm, Sweden (NHRS), where they are arranged by species in four small unit trays supplied with a special label (Fig. 1, as an example). Each unit tray has two kinds of specific labels - a museum label attached to the front wall of the tray (hand-written by an unknown person) and a label with a manuscript name attached to the bottom of the tray (hand-written by Holmgren). Also, some conspecific species of Rhamphomyia deposited in the Zoological Institute of Russian Academy of Sciences, St. Petersburg, Russia (ZISP) and in the Canadian National Collection of Insects, Ottawa, Canada (CNC) were examined. Pinned, dried specimens were studied. Terms used for adult structures primarily follow those summarised by Cumming and Wood [2009]. Habitus photos were produced using a Nikon SMZ 1500 stereomicroscope equipped with Nikon D700 digital SLR camera and were aligned and stacked using the Helicon Focus 5.3.14 software. The purpose of the lectotype designations made in this paper is to assure correct and consistent application of the names.

\section{Taxonomic account}

Class Insecta Linnaeus, 1758

Order Diptera Linnaeus, 1758

Suborder Brachycera Macquart, 1834

Superfamily Empidoidea Latreille, 1804

Family Empididae Latreille, 1804

\section{brusewitzii Holmgren, 1880: 20}

(male and female, Rhamphomyia)

CURRENT COMBINATION: Rhamphomyia (Dasyrhamphomyia) brusewitzii Holmgren, 1880.

CURRENT STATUS: Valid species.

TAXONOMIC NOTES. The species was described after both sexes but from an unspecified number of specimens. In the unit tray under the museum label "Rhamphomyia kjellmanii Holmgren, 1880" and the manuscript name "Rh. juncta $\mathrm{n}$. sp." there is one female with three labels (6. [hand-written]; 14 [printed]; Brusewitzi [Holmgren hand-written] (Fig. 1), as well as one male and one female with only one label (8. and 4., respectively). All specimens are definitely conspecific and agree with the original description. The only male (with label
8.) is selected as the lectotype of Rhamphomyia brusewitzii Holmgren, 1880 and labelled accordingly to fix the name of this species (Fig. 2). The remaining two specimens are labelled as paralectotypes. The lectotype is in good condition. Type locality: not given (Novaya Zemlya Islands ["Matotschkin, Skoddebay" after Holmgren and Aurivillius, 1883: 163], Arkhangelskaya Province, Russia).

Until now $R$. brusewitzii has not been recognised correctly. Frey (the noted empidid specialist of the first half of the $20^{\text {th }}$ century, who studied Rhamphomyia extensively), apparently never examined species described by Holmgren. He noted $R$. brusewitzii (as R. brusewitzi) in his earlier papers [Frey, 1915, 1922] and even identified correctly this species from Taymyr [Frey, 1915: 11]. However, Frey suddenly synonymised $R$. brusewitzii with $R$. hovgaardii in "Die Fliegen" [Frey, 1955: $516]$ without comment. This synonymy was followed by all subsequent authors of Empididae catalogues [Chvála, Wagner, 1989: 286; Yang et al., 2007: 183; Shamshev, 2016: 76]. Comparison of type material of $R$. brusewitzii and $R$. hovgaardii showed that, in fact, they are separate species and can be distinguished in the following way:

1. Mesonotal setae strong, bristle-like. Smaller, 5.5-6.0 $\mathrm{mm}$. Male: eyes dichoptic; ommatidia of equal size; frons very narrow on middle part, at most slightly broader than anterior ocellus. Female: legs with ordinary setae.......... R. brusewitzii Holmgren

- Mesonotal setae almost uniformly thin, hair-like. Larger, 7.0-7.5 mm. Male: eyes holoptic, touching or almost touching for short portion; upper ommatidia enlarged. Female: mid femur with posteroventral pennate setae (except extreme base); hind femur with rather short anterodorsal and moderately long posteroventral pennate setae throughout; hind tibia with numerous subpennate to long pennate anterodorsal and shorter anteroventral setae (except narrow subapical and basal parts ......... R. hovgaardii Holmgren Consequently, we raise the name Rhamphomyia brusewitzii Holmgren, 1880, stat. nov., from synonymy. The redescription of $R$. brusewitzii is given below.

Frey [1915: 11] described $R$. anomalinervis as var. of "brusewitzi" Holmgren after a male taken from "West-Taimyr, Nordküste, Sarja-Hafen" of Russia [see for details: Shamshev, 2016: 76]. We have examined this specimen and confirm that it is conspecific with R. brusewitzii.

RE-DESCRIPTION. Male (Fig. 3). Body length: 5.6-6.1 $\mathrm{mm}$ (lectotype 5.9); wing length: 6.0-6.3 mm (lectotype 6.1). Head black in ground colour, with black setation. Eyes dichoptic; ommatidia of equal size. Frons very narrow on middle part, at most slightly broader than anterior ocellus, leaving small triangular space below ocellar tubercle and larger subtriangular space above antennae, densely brownish grey dusted, with marginal setulae. Face somewhat broader than frons above antennae, divergent downwards, bare, densely brownish grey pollinose; margins of clypeus and gena subshiny to shiny. Ocellar tubercle with 2 moderately long and several short setae. Occiput densely brownish grey pollinose; with numerous long to moderately long bristles on upper portion and some thin moderately long setae on lower portion. Antenna black; scape and postpedicel short, scape somewhat longer, both with very short setae; postpedicel conical (shape slightly variable), nearly 2.5 times longer than wide; stylus short, nearly $1 / 3$ of postpedicel length. Labrum brownish; slightly longer than head height. Palpus black, with scattered black, short setae.

Thorax black in ground-colour, with black setation, densely pollinose. Scutum in anterior view densely brownish pollinose, somewhat darker between rows of acrostichals and dorsocentrals; in dorsal view with indistinct darker vittae beneath rows of 
acrostichals and dorsocentrals. First cervical sclerite bare. Prosternum bare. Proepisternum with several moderately long bristles on lower portion and 1-2 similar setae on upper portion. Antepronotum convex, with about 8 short bristles on each side dorsally. Postpronotal lobe with numerous intermixed moderately long bristles and bristly hairs, 1 bristle usually somewhat longer. Mesonotal setae strong, bristle-like, including dorsocentrals and acrostichals (setation very unstable, number, robustness and position variable, sometimes differing on right and left sides); 3-5 moderately long presutural supra-alars (sometimes not arranged in row), numerous postsutural supra-alars extending to base of postalar tubercle, notopleuron with $8-12$ (in lectotype 8) long bristles (often with additional shorter setae), postalar tubercle with tuft of several moderately long to long bristles, scutellum with 5-6 setae of different lengths on each side; dorsocentrals arranged in 2 closely set irregular rows throughout (sometimes 3-serial anteriorly or sparser and almost uniserial before scutellum), numerous, rather long prescutellars longest; acrostichals as long to slightly shorter than dorsocen- trals, arranged in two closely set irregular rows. Laterotergite with rather sparse setae of different lengths. Spiracles brown.

Legs robust, entirely dark brown, uniformly faintly greyish pollinose, with black setation. Coxae and trochanters with numerous bristles of different lengths. Femora of subequal width, hind tibia somewhat thicker than fore and mid tibiae, tarsomeres of all legs slender. Fore femur faintly pubescent ventrally, with numerous short to moderately long, bristle-like anteroventral and posteroventral setae arranged irregularly (not forming regular rows), without setae ventrally (except near extreme base). Fore tibia with 5-7 short anterodorsal and similar posterodorsal bristles (number and position variable). Fore tarsomeres with very short subapicals, otherwise covered with ordinary setulae. Mid femur with similar pattern of setation to fore femur, including faint ventral pubescence, but anteroventral and posteroventral setae shorter, more numerous and rather spine-like, posteroventrals longer. Mid tibia shorter than fore and hind tibiae, bearing several short anterodorsal and posterodorsal bristles, with some spinule-like setae on subapical part ventrally. Mid
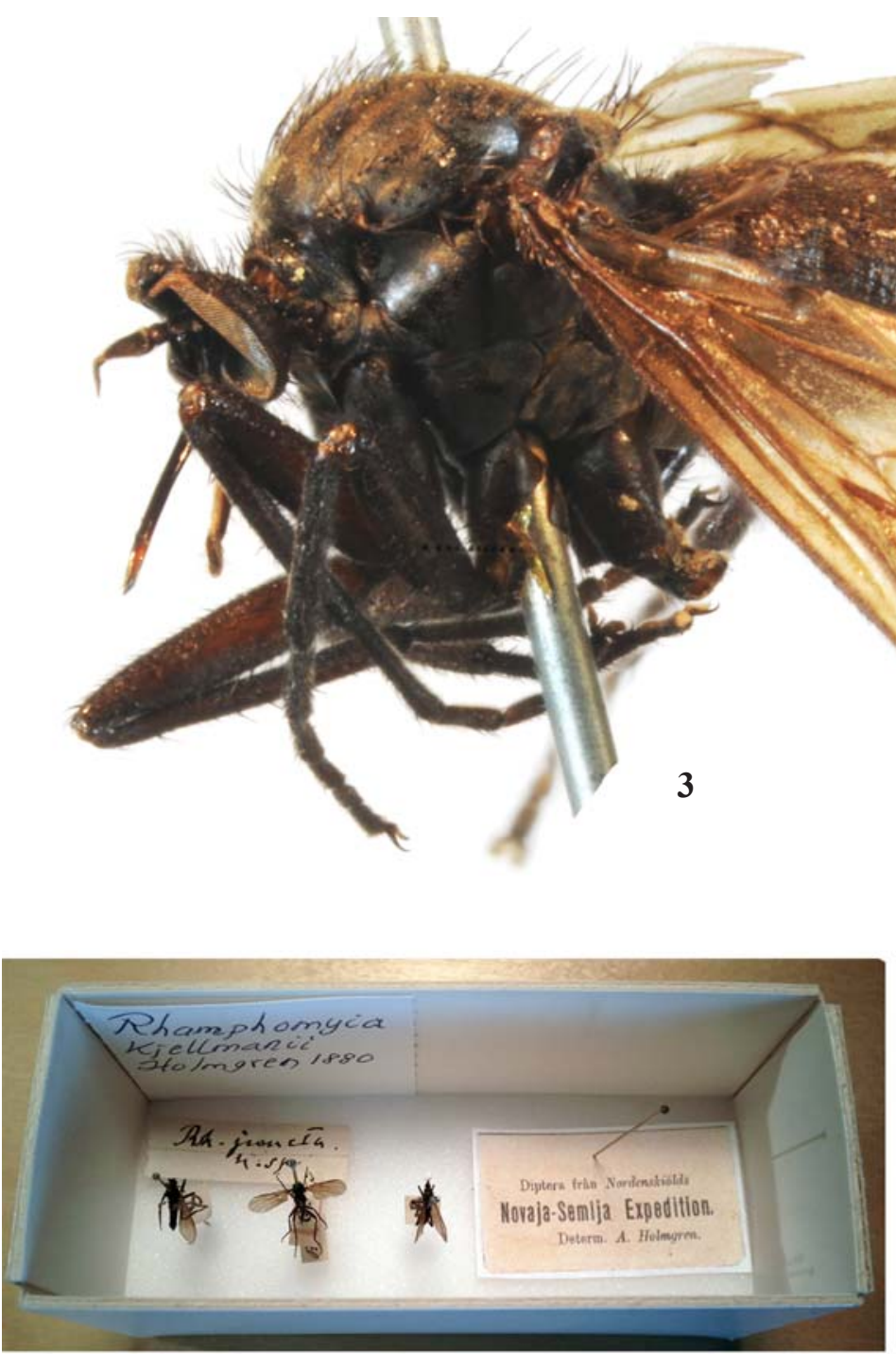

Figs 1-3. Rhamphomyia (Dasyrhamphomyia) brusewitzii Holmgren, 1880: 1 - syntypes; 2 - lectotype labels; 3 - lectotype male, lateral view.

Рис. 1-3. Rhamphomyia (Dasyrhamphomyia) brusewitzii Holmgren, 1880: 1 - синтипы; 2 - этикетки лектотипа; 3 - лектотип, самец, сбоку. 
basitarsus with several short spine-like setae ventrally, otherwise mid tarsomeres covered with ordinary setulae (except circlet of short subapical bristles). Hind femur unmodified; whitish pubescence ventrally more distinct than fore and mid femora, with very short to short numerous anteroventral and posteroventral bristle-like setae throughout, otherwise covered with ordinary setulae. Hind tibia with numerous short anterodorsal and posterodorsal bristles, with ordinary setulae ventrally. Hind basitarsus with 1 short anterodorsal bristle near middle and several anteroventral and posteroventral spine-like short setae; otherwise hind tarsomeres covered with ordinary setulae (except circlet of short subapical bristles).

Wing uniformly brownish infuscate. Veins brownish; anal vein complete; veins $M_{1}$ on apical portion, $M_{2}$ and veins closing cell $\mathrm{dm}$ thinner. Basal costal bristle absent. Pterostigma brownish. Veins $R_{4+5}$ and $M_{1}$ broadly sinuate, parallel near wing-margin. Cell $\mathrm{dm}$ somewhat elongate. Anal angle close to right, anal lobe well developed. Calypter yellowish brown, darkly fringed. Halter brownish.

Abdomen black, covered with almost uniform black very short bristly hairs longer on tergites 1-2 laterally; tergites faintly brownish pollinose, in lateral view rather subshiny; sternites slightly denser pollinose. Terminalia rather moderately large, epandrium and cerci brownish to yellowish brown, with scattered short, black hair-like setae; cerci prolonged anteriorly nearly to middle of tergite 5 ; phallus broadly exposed, yellow, evenly bowed, thickened near basal $2 / 3$.

Female. Body length 5.2-5.5 mm, wing length 5.5-5.7 $\mathrm{mm}$. Similar to male but frons very broad, almost parallelsided; mesonotum with somewhat shorter and less numerous acrostichal and dorsocentral setae, former clearly shorter; abdomen with shorter setation. Cercus concolorous with abdomen, slender, with minute setulae.

DISTRIBUTION. PALAEARCTIC: Russia (Arkhangelskaya Province (Novaya Zemlya), Krasnoyarskiy Territory (Taymyr)).

\section{hovgaardii Holmgren, 1880: 21}

(male and female, Rhamphomyia)

CURRENT COMBINATION: Rhamphomyia (Dasyrhamphomyia) hovgaardii Holmgren, 1880.

CURRENT STATUS: Valid species.

TAXONOMIC NOTES. The species was described after both sexes but from an unspecified number of specimens. In the unit tray under the museum label "Rhamphomyia hovgaardi Holmgren, 1880" and the manuscript name " $R h$. dasypoda n. sp.", the following specimens are deposited: one male labelled "6.; Hofgaardi [Holmgren hand-written]"; one male labelled "6."; one male, two females labelled "2". All specimens are definitely conspecific and agree with the original description. The male with original specific label (6.; Hofgaardi) is selected as the lectotype of Rhamphomyia hovgaardii Holmgren, 1880 and labelled accordingly to fix the name of this species (Fig. 4). The remaining four specimens are labelled as paralectotypes. The lectotype is in good condition but the left tibia and tarsus, right hind tibia and tarsus and left hind tarsomeres $2-5$ are missing. Type locality: not given (Novaya Zemlya Islands ["Waigatsch. Norra och Södra Gåskap" after Holmgren and Aurivillius, 1883: 163], Arkhangelskaya Province, Russia). The re-description of $R$. hovgaardii is given below.

RE-DESCRIPTION. Male (Fig. 5) Body length 6.9-7.5 (lectotype 7.2) $\mathrm{mm}$, wing length 6.4-6.9 (lectotype 6.5) $\mathrm{mm}$. Head black in ground colour, with brown to black setation. Eyes holoptic, touching or almost touching for short portion; upper ommatidia enlarged. Frons represented by very small triangular space below ocellar tubercle and larger subtriangular space above antennae, densely brownish grey dusted, without marginal setulae. Face broad, bare, densely brownish grey pollinose; margins of clypeus and gena subshiny to shiny. Ocellar tubercle with 2 moderately long and several shorter hair-like setae. Occiput densely brownish grey pollinose; with

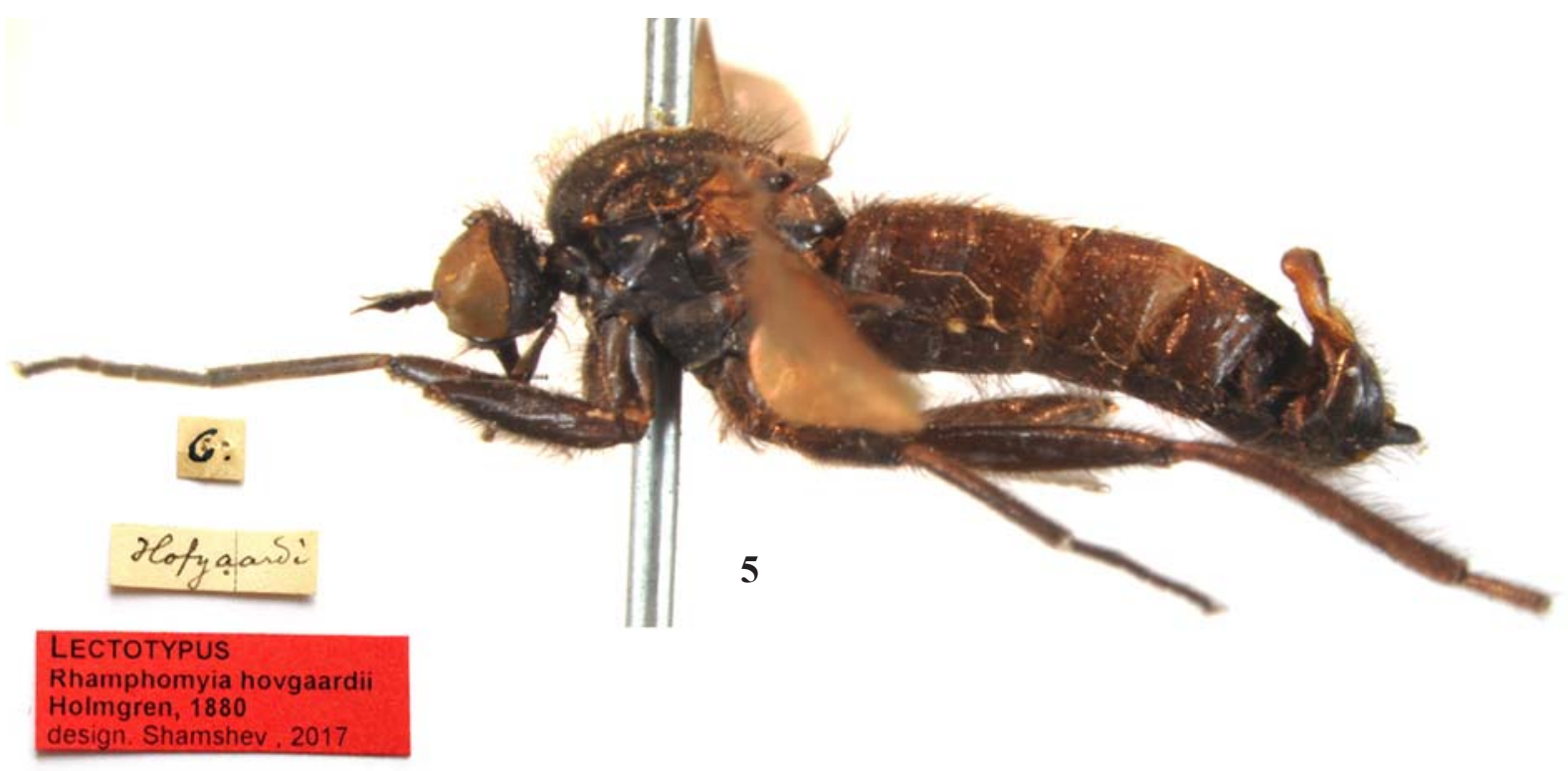

\section{NHRS-BYWS}

000002401

Figs 4-5. Rhamphomyia (Dasyrhamphomyia) hovgaardii Holmgren, 1880: 4 - lectotype labels; 5 - lectotype male, lateral view. Рис. 4-5. Rhamphomyia (Dasyrhamphomyia) hovgaardii Holmgren, 1880: 4 - этикетки лектотипа; 5 - лектотип, самец, сбоку. 
numerous long to moderately long hair-like setae. Antenna black; scape and postpedicel short, both with very short setae; postpedicel conical, 2.5-3.0 times longer than wide; stylus rather long, nearly $2 / 3$ of postpedicel length. Labrum brownish; nearly as long as head height. Palpus black, with numerous black, moderately long hair-like setae.

Thorax black in ground-colour, with black, mostly hair-like setation. Scutum in anterior view dark, densely brownish pollinose, in dorsal view dull dark brown. First cervical sclerite bare. Prosternum bare. Proepisternum with numerous long, hairlike setae on lower portion and several similar setae on upper portion. Antepronotum convex, with numerous short bristles. Postpronotal lobe with numerous long to moderately long hairlike setae. Mesonotal setae almost uniformly thin, hair-like; supra-alar space with numerous long to moderately long setae, notopleuron with similar setation but several setae somewhat stronger, postalar tubercle with tuft of several moderately long to long setae, scutellum with numerous setae of different lengths but 4-5 long setae on each side usually stronger; dorsocentrals arranged in 3-4 irregular rows (sometimes more anteriorly), numerous, long, becoming longer anterior to scutellum; acrostichals nearly as long to somewhat shorter than dorsocentrals, arranged in 2-3 irregular rows. Laterotergite with numerous setae of different lengths. Spiracles brown.

Legs robust, entirely dark brown, uniformly faintly greyish pollinose, with black mostly hair-like setation. Coxae and trochanters with numerous hair-like setae of different lengths. Femora of subequal width, hind tibia somewhat thicker than fore and mid tibiae, tarsomeres of all legs slender. Fore femur faintly pubescent ventrally, clothed in moderately long hair-like setae, with long anteroventral and posteroventral setae arranged irregularly. Fore tibia with short setae dorsally. Fore tarsomeres with very short subapicals, only pubescent ventrally, otherwise covered with ordinary setulae. Mid femur with similar pattern of setation to fore femur, including faint ventral pubescence, but anteroventral and posteroventral setae shorter (especially anteroventrals) and somewhat stronger. Mid tibia shorter than fore and hind tibiae, with dorsal setation similar to fore tibia, bearing spinule-like setae on subapical part ventrally. Mid tarsus with similar setation to fore tarsus. Hind femur unmodified, more distinctly whitish pubescent ventrally than fore and mid femora, clothed in numerous moderately long setae, longer posteriorly. Hind tibia with numerous moderately long setae dorsally, anteroventral setulae stronger, rather spinule-like. Hind basitarsus with several short anteroventral and posteroventral setae; otherwise hind tarsomeres covered with ordinary setulae (except circlet of short subapical bristles).

Wing uniformly brownish infuscate. Veins brownish; anal vein complete; veins $M_{1}$ on apical portion, $M_{2}$ and veins closing cell $\mathrm{dm}$ thinner. Basal costal bristle absent. Pterostigma brownish. Veins $\mathrm{R}_{4+5}$ and $\mathrm{M}$ broadly sinuate, parallel near wing-margin. Cell dm short. Anal angle acute, anal lobe well developed. Calypter yellowish brown, darkly fringed. Halter brownish.

Abdomen black, entirely faintly greyish pollinose; covered with numerous uniform brown, long hair-like setae. Terminalia moderately large; epandrium brown, with scattered short black hair-like setae; cerci brownish yellow, prolonged anteriorly nearly to middle of tergite 5 ; phallus broadly exposed, yellow, thickened on basal $2 / 3$, hook-like on subapical part.

Female. Body length $6.2-6.7 \mathrm{~mm}$, wing length $6.0-6.3$ $\mathrm{mm}$. Similar to male but frons very broad, almost parallelsided, with minute setae; occiput and mesonotum with somewhat shorter setation; legs with shorter hair-like setae; fore and mid basitarsi with ordinary setulae ventrally; mid femur with numerous, long, posteroventral pennate setae (except extreme base) and bearing some shorter subpennate antero- dorsal setae; hind femur with rather short anterodorsal and moderately long posteroventral pennate setae throughout; hind tibia with numerous subpennate to long pennate anterodorsal and shorter anteroventral setae (except narrow subapical and basal parts; anteroventrals are more variable and, sometimes, quite simple); wing slightly broader and darker; abdomen with somewhat shorter setation. Cercus concolourous with abdomen, slender, with minute setulae.

DISTRIBUTION. PALAEARCTIC: Russia (Arkhangelskaya Province (Novaya Zemlya), Chukotka, Krasnoyarskiy Territory (Taymyr), Yakutia). NEARCTIC: Canada.

\section{kjellmanii Holmgren, 1880: 22} (female, Rhamphomyia)

CURRENT COMBINATION: Rhamphomyia (Pararhamphomyia) kjellmanii Holmgren, 1880.

CURRENT STATUS: Valid species.

TAXONOMIC NOTES. The species was described from an unspecified number of females only. In the unit tray under the museum label "Rhamphomyia nordqvisti Holmgren, 1880" and the manuscript name "Rh. praecox $\mathrm{n}$. sp." there is one female with two labels (10.; Kjellmani [Holmgren hand-written]) and six females with only one label (10.). The female specimen with original specific label agrees with the original description of $R$. kjellmanii, is selected as the lectotype and labelled accordingly to fix the name of this species (Fig. 6). The remaining specimens are probably conspecific but they are quite variable in some characters and only an identification label is attached. The lectotype (Fig. 7) is in good condition; pollinosity of thorax somewhat dissolved by humidity, and on the right wing cell $\mathrm{dm}$ is open (the same in one other specimen). The re-description of the lectotype is given below. Type locality: not given (Novaya Zemlya Islands, Arkhangelskaya Province, Russia).

ADDITIONAL NOTES. In the unit tray with manuscript name "Rh. melanophora n. sp." one male and two females without labels (see below) were found. The females are conspecific with $R$. kjellmanii and the male could be associated with this species.

RE-DESCRIPTION. Female (Fig. 7). Body length: 4.1 $\mathrm{mm}$; wing length: $4.0 \mathrm{~mm}$. Head black in ground colour, with black setation. Eyes dichoptic. Frons broad, above antennae nearly 2 times broader than postpedicel on basal part, slightly broadened just below ocellar tubercle, with several minute marginal setulae, entirely densely brownish grey pollinose. Face nearly as broad as frons above antennae, bare, densely brownish grey pollinose; margins of clypeus and gena subshiny to shiny. Ocellars missing, only minute setulae present. Occiput densely greyish pollinose; mainly with numerous long bristles arranged irregularly, bearing some slightly paler, short, hair-like setae on lower portion. Antenna with scape and pedicel brownish, postpedicel and stylus black; scape and postpedicel short, both with minute setulae; postpedicel conical, 4 times longer than wide; stylus very short, 1/4 of postpedicel length. Labrum brownish; nearly as long or slightly longer then head height. Palpus black, with scattered black short bristly hairs.

Thorax black in ground-colour, with black setation (except laterotergal setae), densely greyish pollinose. First cervical sclerite bare. Prosternum bare. Proepisternum with 3 stronger black and 3 shorter brownish yellow setae on lower portion, bare on upper portion. Antepronotum convex, with 5 very short black bristles on each side dorsally. Postpronotal lobe with 2 long bristles surrounded by several shorter setae. Mesonotum with 1 moderately long presutural supra-alar, 3(?) postsutural supra-alars, 6-7 notopleurals, 1 long postalar and 6 scutellars (apical pair very long); dorsocentrals of different lengths, longest ones rather moderately long (except 
very long prescutellars), arranged in single, nearly regular row, numerous, closely set, flanked with 1 additional bristle anteriorly; acrostichals as long to slightly shorter than dorsocentrals, arranged in two irregular rows (less distinct anteriorly). Laterotergite with numerous pale yellow setae of different lengths. Spiracles brown.

Legs rather short, robust, dark brown; femora of subequal width, quite shiny, other podomeres faintly greyish pollinose (except hind coxa anteriorly). Coxae with black blunt-tipped bristles and some pale yellow hair-like setae. Trochanters with only scattered pale yellow hair-like setae. Fore femur with ordinary setation, almost bare ventrally, anteroventral and posteroventral setae minute. Fore tibia with ordinary setation somewhat longer posteriorly; bristles of subapical circlet short (except 1 anterodorsal and 1 posteroventral). Fore basitarsus with several more prominent short ventral setae, otherwise with ordinary setation, bristles of subapical circlet short. Mid femur whitish pubescent ventrally, with very short anteroventral and longer posteroventral setae. Mid tibia somewhat shorter and thicker than fore tibia, with regular row of numerous short posteroventral setae, bristles of subapical circlet moderately long. Mid basitarsus with numerous ventral, short spine-

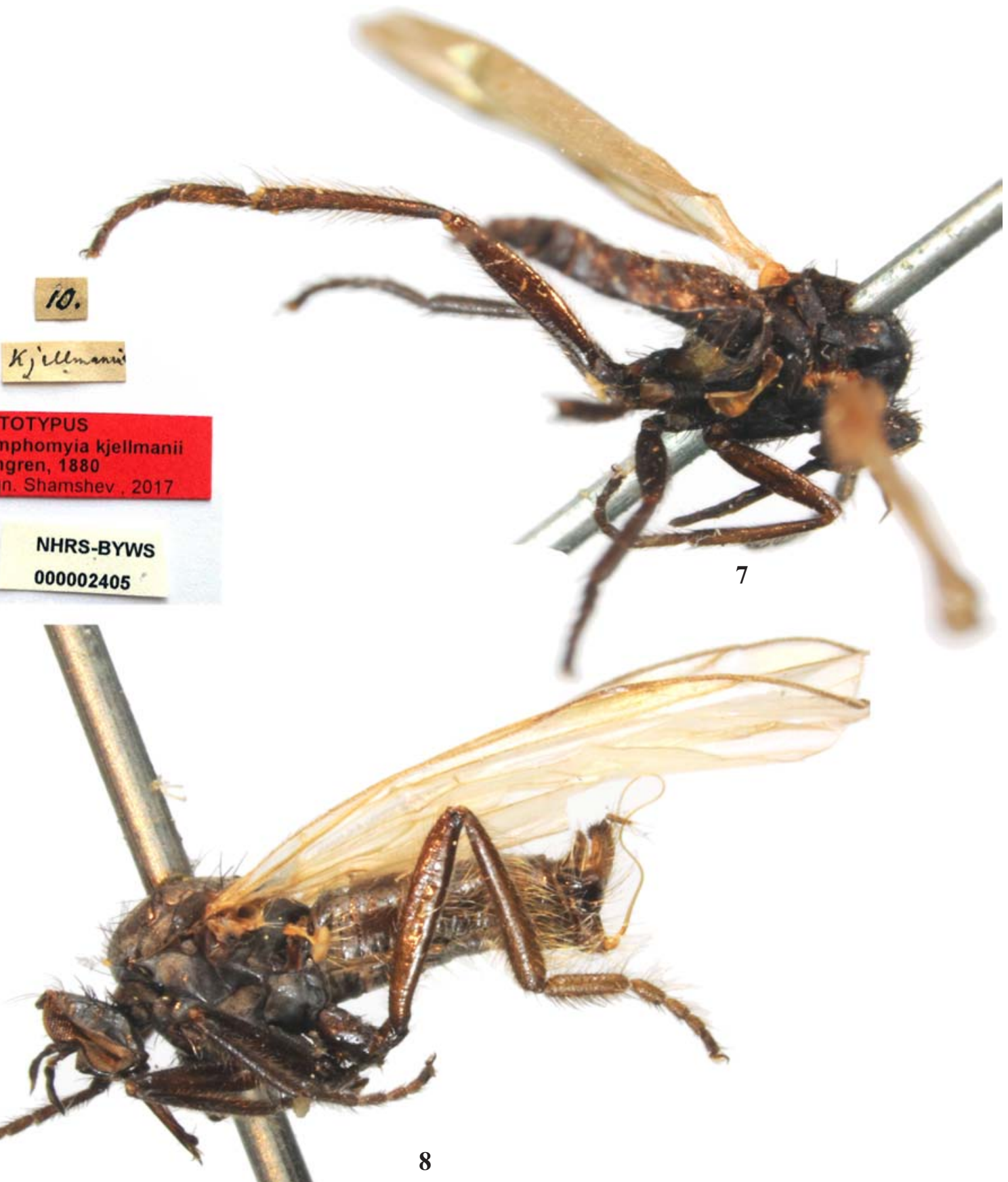

Figs 6-8. Rhamphomyia (Pararhamphomyia) kjellmanii Holmgren, 1880: 6 - lectotype labels; 7 - lectotype female, postero-lateral view; 8 - male, lateral view.

Рис. 6-8. Rhamphomyia (Pararhamphomyia) kjellmanii Holmgren, 1880: 6 - этикетки лектотипа; 7 - лектотип, самка, сзади и сбоку; 8 - самец, сбоку. 
like bristles, otherwise mid tarsus with ordinary setation (except circlet of short subapicals). Hind femur whitish pubescent ventrally, with short to moderately long (on subapical part, where some of them only slightly longer than half of femur depth) anteroventral and posteroventral setae. Hind tibia slightly thickened towards apex; closed in numerous dense brownish to brownish yellow thin setae, longer on subapical part dorsally. Hind basitarsus with longer setae dorsally (similar to setae on hind tibia) and numerous spine-like setae ventrally.

Wing uniformly brownish infuscate. Veins brownish to brownish yellow; anal vein very faint on subapical portion, rather incomplete; veins $M_{1}$ on apical portion, $M_{2}$ and veins closing cell $\mathrm{dm}$ thinner, $\mathrm{R}$ veins somewhat thicker. Basal costal bristle very short. Pterostigma indistinct. Vein $R_{4+5}$ broadly sinuate, meeting costa before wing-tip, parallel to vein $\mathrm{M}_{1}$ near wing margin. Cell $\mathrm{dm}$ somewhat elongate (part of vein $\mathrm{M}_{2}$ absent). Anal angle right, anal lobe well developed. Calypter yellow, pale fringed. Halter yellow.

Abdomen brownish black, tergites (except segments 6-8) almost shiny, very faintly greyish pollinose, sternites and segments 6-8 denser pollinose; covered with short, pale hairlike setae; cercus long, slender, concolourous with abdomen, clothed in minute setulae.

Male (Fig. 8, described for the first time). Body length 3.8 $\mathrm{mm}$, wing length $4.3 \mathrm{~mm}$. Eyes holoptic, with upper ommatidia distinctly enlarged. Thorax as in female, acrostichals somewhat thinner and more distinctly shorter than dorsocentrals; 4 6 notopleurals (variation on different sides). Legs: fore tibia dorsally and posteriorly and mid tibia clothed in numerous long, hair-like setae, mid tibia with longer anterodorsal subapical bristle; fore and mid tarsi with somewhat longer dorsal setae; hind tibia evenly thickened towards apex, clothed in dense long brownish to yellowish brown hair-like setae ventrally and even much longer curved setae on other surfaces, similar erect setae expanding to hind tarsomeres 1-4 but becoming shorter; hind tarsomeres 1-2 thickened. Wing almost hyaline; otherwise as in female. Abdomen (lateral view) with tergites extensively polished, entire tergite 1 and tergite 2 anteriorly densely pollinose; sternites (lateral view) contrastingly densely greyish pollinose, but sternite 8 subshiny; covered with numerous pale hair-like setae longer on tergites laterally, on posterior margin of tergite 8 and on sternites, sternite 8 with similar long uniform setae along hind margin. Hypopygium moderately large; epandrial lobe brownish on basal part and yellowish brown on apical part; with attenuated apex; covered with long, pale hair-like setae, with some minute black setae on subapical part; phallus well exposed, long, thin (slightly thicker on more or less straight basal part), with broad loop on about middle.

DISTRIBUTION. PALAEARCTIC: Russia (Arkhangelskaya Province (Novaya Zemlya), Yakutia). NEARCTIC: Canada.

\section{nordqvistii Holmgren, 1880: 23}

(female, Rhamphomyia).

CURRENT COMBINATION: Rhamphomyia (Pararhamphomyia) nordqvistii Holmgren, 1880

CURRENT STATUS. Valid species.

TAXONOMIC NOTES. This is the most problematic species, as it was described from an unspecified number of females only. However, in the later paper Holmgren [Holmgren, Aurivillius, 1883: 164] indicates male after the diagnosis, but this is probably a mistake because he provides a description of the female. In contrast to the other three species, no specimen among Holmgren's material has an original specific label with the name "nordqvistii". In the unit tray with the museum label "Rhamphomyia melanophora Holmgren" and the manuscript name "Rh. melanophora $n$. sp." there are four females bearing the label "9." as well as one male and two females without labels. These specimens belong to two different species. One male and two females without labels are conspecific and the same species as "Rh. praecox" (=R. kjellmanii) (see above). Four females with the label "9." are conspecific and differ clearly from the other species described by Holmgren. These specimens are somewhat variable in body size and some other characters, but generally they agree with the original description of $R$. nordqvistii. Thus, there is probably reason to believe that the four females with label "9." are syntypes of $R$. nordqvistii. Acting as First Reviser, a female was selected as the lectotype and labelled accordingly to fix the name of this species (Fig. 9). However, only an identification label is attached to the remaining three specimens. The lectotype (Fig. 10) is in good condition. The re-description of the lectotype is given below. Type locality: not given (Novaya Zemlya Islands, Arkhangelskaya Province, Russia).

ADDITIONAL NOTES. There are several cases of incorrect spelling of original name of $R$. nordqvistii by subsequent authors, those have been listed by Shamshev [2016: 66].

Frey [1922: 41] described $R$. eunordquisti (as var. of $R$. obscura (Zetterstedt, 1838)) after females taken from "NordSibirien (Dudinka) and Kamtschatka" of Russia. This species was synonymised later with $R$. nordqvistii [Frey, 1955: 490; Chvála, Wagner, 1989: 303]. We have examined a female of $R$. eunordquisti identified by Frey and deposited in NHRS (labelled: Kamtschatka, Malaise; 3221; Rhamphomyia eunordqvisti Frey [hand-written by Frey], R. Frey det. [noted in Frey, 1935: 2]). This specimen differs clearly from $R$. nordqvistii and consequently the type material of $R$. eunordquisti should be examined to clarify the status of this species.

RE-DESCRIPTION. Female (Fig. 10). Body length: 2.9 $\mathrm{mm}$; wing length: $3.2 \mathrm{~mm}$. Head black in ground colour, with black setation. Eyes dichoptic. Frons broad, broadened just below ocellar tubercle, with several minute marginal setulae, entirely brownish grey pollinose. Face shrunken. Ocellars almost entirely missing, only 1 moderately long thin seta present on left side of ocellar tubercle. Occiput greyish pollinose; with numerous brown to black thin setae longer on upper part. Antenna entirely brown; scape and pedicel short, both with minute setulae; postpedicel conical, 4 times longer than wide; stylus very short. Labrum brownish; nearly as long as head height. Palpus black, with scattered black short bristly hairs.

Thorax black, with black to brown setation, including metapleural setae; all setae thin, hair-like; mesonotum partly obscured by pin, in visible part uniformly brownish grey pollinose. Proepisternum with 3 moderately long setae on lower portion and with 3 short setae on upper portion. Antepronotum with several short setae on each side. Postpronotal lobe with 1 longer and several shorter setae. Main mesonotal setae thin, rather bristly hairs, hardly distinguishable; presutural supra-alar space covered with several setae of different lengths but 2 of them longer, 2 postsutural supra-alars with additional shorter setae, 4 notopleurals of different lengths (1 longer), 1 postalar, 6 scutellars (4 stronger); dorsocentrals rather long (prescutellars probably longest but are partly broken), arranged in 2-3 irregular rows and hardly distinguishable from supra-alar setae anteriorly, becoming uniserial in front of scutellum; acrostichals obscured by pin, apparently arranged in 2 irregular rows (at least near anterior margin of scutum). Spiracles brown.

Legs quite slender, entirely brownish, faintly greyish pollinose, with black to brown ordinary setae only. Coxae with thin setae. Femora of subequal width, whitish pubescent ventrally. Fore femur with short anteroventral and posteroventral 
thin setae. Fore tibia with longer setae posterodorsally and posteriorly (some setae somewhat longer). Fore basitarsus with some stronger setae ventrally. Mid femur with minute anteroventral and posteroventral setae. Mid tibia with 4-5 short, thin anterodorsal and 4-5 similar posterodorsal setae, with somewhat stronger short anteroventral setae toward apex. Mid basitarsus with slightly longer setae dorsally and short spine-like setae ventrally. Hind femur slender, with short anteroventral and posteroventral setae. Hind tibia somewhat thicker than fore and mid tibiae, with some prominent short, stronger anterodorsal and posterodorsal setae and stronger ventral subapical setae. Hind basitarsus somewhat thicker than fore and mid basitarsus, with short spine-like setae ventrally.

Wing uniformly brownish infuscate, no distinct basal costal seta. Veins brownish to brownish yellow; veins $M_{1}$ on apical portion, $\mathrm{M}_{2}$ and veins closing cell $\mathrm{dm}$ thinner, $\mathrm{R}$ veins somewhat thicker. Pterostigma indistinct. Vein $\mathrm{R}_{4+5}$ broadly sinuate, meeting costa before wing tip, parallel to $M_{1}$ near wing margin; anal vein incomplete. Cell $\mathrm{dm}$ somewhat elongate. Anal angle right, anal lobe well developed. Calypter brownish yellow, brownish fringed. Halter entirely brownish.

Abdomen dark brown, faintly greyish pollinose, subshiny (lateral view), covered with short brownish setae; cercus long, slender, concolourous with abdomen, clothed in minute setulae.

Male. Unknown.

DISTRIBUTION. PALAEARCTIC: Russia (Arkhangelskaya Province (Novaya Zemlya), (?)Kamchatskiy and (?)Krasnoyarskiy Territories (Taymyr), (?)Yakutia.

ACKNOWLEDGEMENTS. We are indebted to Yngve Brodin (NHRS) for the loan of specimens used in our study. Our special thanks are due to Neal Evenhuis (Bernice Pauahi Bishop Museum, Honolulu, USA) for his explanation of some taxonomic and bibliographic questions. Fedor Konstantinov (Department of Entomology, St. Petersburg State University, St. Petersburg, Russia) kindly provided equipment for making digital images. The study of Igor Shamshev was performed within the frames of the Russian State Research Project no. AAAA-A17-117030310210-3 and supported by the Russian Foundation for Basic Research (grant no. 18-04-00354A•) and the Presidium RAS program no.41 "Biodiversity of natural systems and biological sources of Russia". Also, Igor Shamshev is grateful to Kjell Arne Johanson and Emma Wahlberg for their help during his visit to NHRS.

\section{References}

Chvála M., Wagner R. 1989. Family Empididae // Soós Á., Papp L. (eds.). Catalogue of Palaearctic Diptera. Vol.6. Therevidae Empididae. Budapest: Akadémiai Kiadó. P.228-336.

Cumming J.M., Wood D.M. 2009. Adult morphology and terminology // Brown B.V., Borkent A., Cumming J.M., Wood D.M. Zumbado M. (eds.). Manual of Central American Diptera. Vol.1. Ottawa: NRC Research Press. P.9-50.

Frey R. 1915. Diptera-Brachycera aus den arktischen Küstengegenden Sibiriens. Résultats scientifiques de l'expédition polaire Russe en 1900-1903, sous la direction du Baron E. Toll, Section E: Zoologie. Volume II, livr. 10 // Zapiski Rossiyskoy Akademii Nauk po Fiziko-Matematicheskomu Otdeleniyu (Transactions of the Russian Academy of Sciences for Physical and Mathematical Branch). Sér.8. Vol.29. No.10. P.1-35.

Frey R. 1922. Vorarbeiten zu einer Monographie der Gattung Rhamphomyia Meig. (Dipt., Empididae) // Notulae Entomologicae. Vol.2. P.1-77.

Frey R. 1935. Entomologische Ergebnisse der schwedischen Kamtschatka-Expedition 1920-1922. 36. Diptera Brachycera. 5. Empididae, Micropezidae, Lauxaniidae, Chloropidae // Arkiv för Zoologi. Bd.28A. Nr.10. S.1-8.

Frey R. 1955. 28. Empididae // Die Fliegen der palaearktischen Region. Bd.4(4). S.481-528. Taf.43-48 (Lfg.183).

Holmgren A.E. 1880. Novas species insectorum cura et labore A. E. Nordenskiöldii e Novaia Semlia coactorum. Holmiae [= Stockholm]: Beckmanniana. 24 pp.

Holmgren A.E., Aurivillius C. 1883. Insecta a viris doctissimis Nordenskiöld illum ducem sequentibus in insulis Waigatsch et Novaja Semlia anno 1875 collecta // Entomologisk Tidskrift. Vol.4. P.139-194.

Leslie A. 1879. The Arctic Voyages of Adolf Erik Nordenskiöld, 1858-1879. London: Macmillan and Co. xiv + $440 \mathrm{pp.}$

Shamshev I.V. 2016. An annotated checklist of empidoid flies (Diptera: Empidoidea, except Dolichopodidae) of Russia // Proceedings of the Russian Entomological Society. Vol.87. P.1184.

Yang D., Zhang K.Y., Yao G., Zhang J.H. 2007. World Catalog of Empididae (Insecta: Diptera). Beijing: China Agricultural University Press. 599 pp.

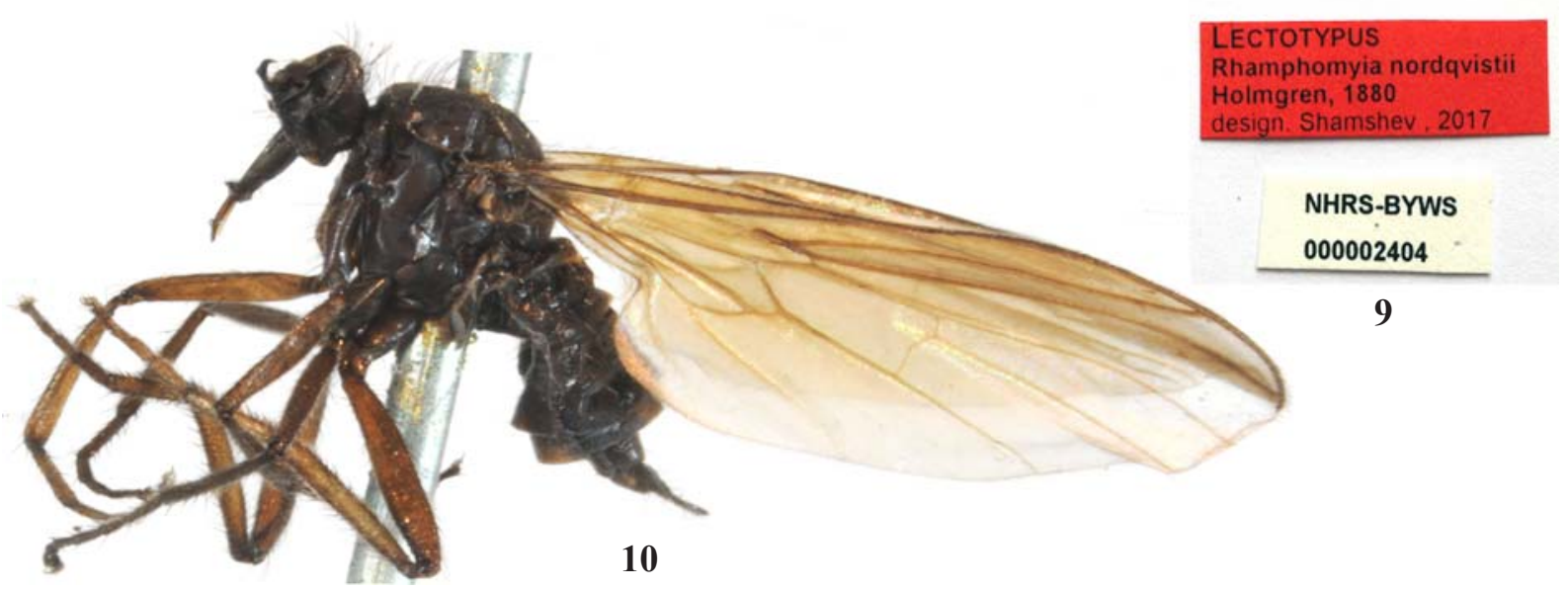

Figs 9-10. Rhamphomyia (Pararhamphomyia) nordqvistii Holmgren, 1880: 9 - lectotype labels; 10 - lectotype female, lateral view. Рис. 9-10. Rhamphomyia (Pararhamphomyia) nordqvistii Holmgren, 1880: 9 - этикетки лектотипа; 10 - лектотип, самка, сбоку. 